Abstract-The jumbo flying squid (Dosidicus gigas) is widely distributed in the eastern Pacific Ocean and its population structure is complex. Morphometric analysis of hard structures of cephalopods is frequently employed to explore the geographic variation within discreet population units. In this study, 8 morphometric characteristics of the gladius, or pen, were measured and compared from 562 jumbo squid specimens collected off Peru, the Costa Rica Dome, and from the equatorial central eastern Pacific. The growth rate of the gladius was evaluated by comparing it with the ages determined from statoliths. Results showed significant differences in gladii morphology between sexes and geographic populations. Stepwise discriminant analysis indicated that gladius morphometric characteristics were suitable discriminatory variables with an overall correct classification rate of $78.6 \%$ for distinguishing different populations. Higher daily growth rates were found in the proostracum than in the conus, possibly because of the different biological functions of these anatomical parts. These results support our general hypothesis that gladius morphology provides an alternative way to distinguish potential geographic populations of $D$. gigas and it adds new information regarding the gladius of the Ommastrephidae.

Manuscript submitted 3 March 2017. Manuscript accepted 7 November 2017. Fish. Bull. 116:50-59 (2018).

Online publication date: 7 December 2017. doi: 10.7755/FB.116.1.5

The views and opinions expressed or implied in this article are those of the author (or authors) and do not necessarily reflect the position of the National Marine Fisheries Service, NOAA.

\title{
Geographic variations of jumbo squid (Dosidicus gigas) based on gladius morphology
}

\author{
Yi Gong' \\ Xinjun Chen $1,2,3,4$ \\ Yunkai Li (contact author) ${ }^{1,2,3,4}$ \\ Zhou Fang'
}

Email address for contact author: ykli@shou.edu.cn

${ }^{1}$ College of Marine Sciences

Shanghai Ocean University

999 Huchenghuan Road

Shanghai, 201306, China

2 The Key Laboratory of Sustainable Exploitation of Oceanic Fisheries Resources Ministry of Education

999 Huchenghuan Road

Shanghai 201306, China

${ }_{3}$ National Engineering Research Centre for Oceanic Fisheries Shanghai Ocean University

999 Huchenghuan Road

Shanghai 201306, China

${ }^{4}$ National Demonstration Center for Experimental Fisheries Science Education Shanghai Ocean University

999 Huchenghuan Road

Shanghai 201306, China

Morphometric analysis has been an accepted method for studying the geographic variation of population units within species of cephalopods (Nesis, 1993; Crespi-Abril et al., 2010; Liu et al., 2015a; van der Vyver et al., 2016). Cephalopods show high phenotypic plasticity in both soft and hard structures owing to their biological characteristics, such as rapid growth, short life span, and highly migratory activity (Crespi-Abril et al., 2010; Arkhipkin et al., 2015; van der Vyver et al., 2016). Therefore, morphometric analysis may be a useful approach for studying geographic variations in pelagic cephalopods that have an extensive distribution range.

The jumbo flying squid (Dosidicus gigas) is widely distributed in the eastern Pacific Ocean, extending from Alaska $\left(60^{\circ} \mathrm{N}\right)$ to Chile $\left(46^{\circ} \mathrm{S}\right)$ and stretching to the west $\left(125^{\circ}\right.$ $140^{\circ} \mathrm{W}$ ) at the Equator (Nigmatullin et al., 2001; Ibáñez and Cubillos, 2007). As a pelagic cephalopod, $D$. gigas has an important ecological function in marine ecosystems, not only as a voracious predator but also as a valuable source of prey (Field et al., 2007; Alegre et al., 2014). It also supports an important commercial fishery, and in 2014 the annual catch exceeded 1,000,000 metric tons (FAO, 2016). The main fishing regions are located off the coasts of Chile and Peru, off the Costa Rica Dome and within the Gulf of California.

Throughout its geographic range, the population structure of $D$. gigas is complicated and often debated. In the past, three distinguishable groups with a different size-at-ma- 


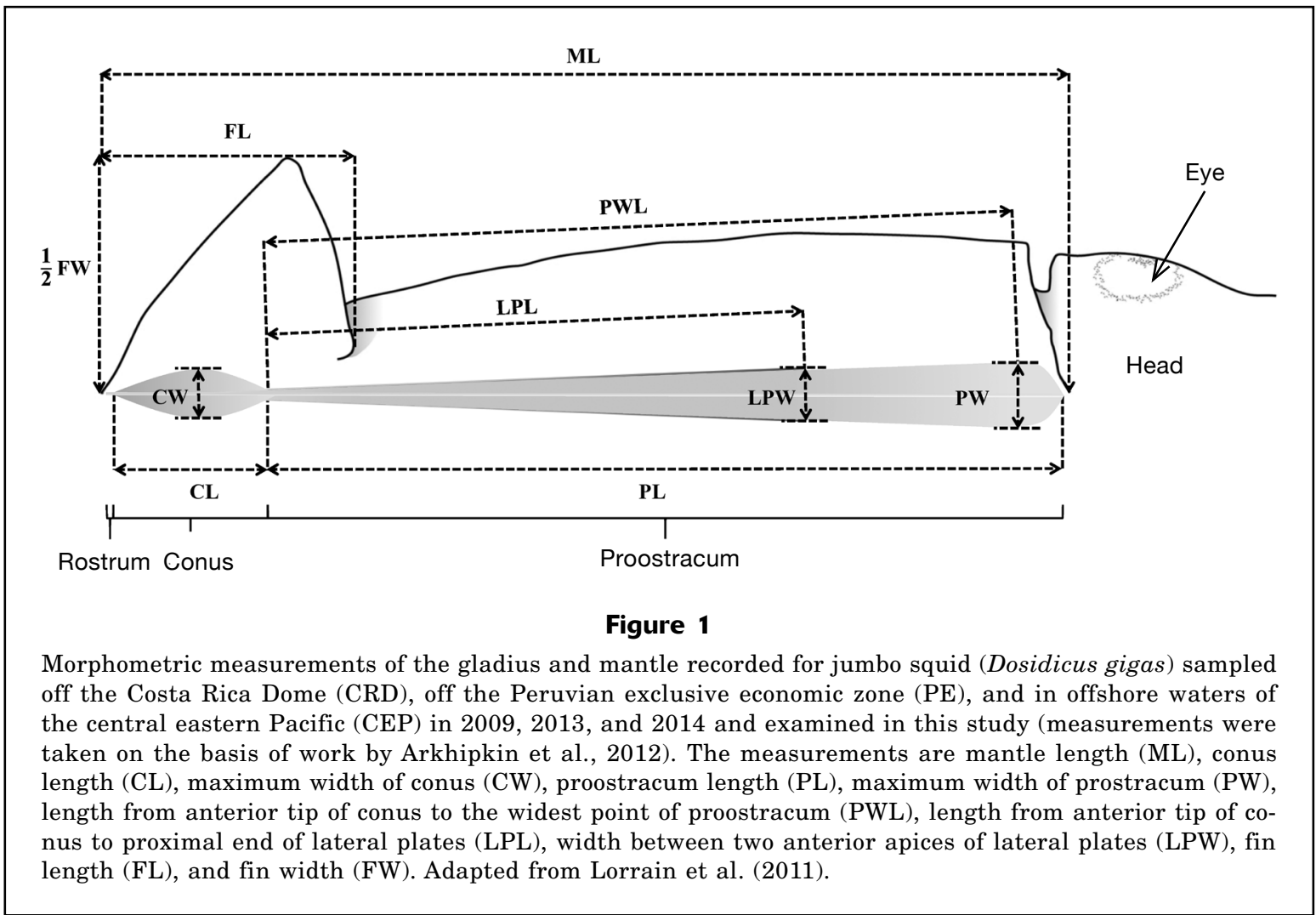

turity have been identified (Nigmatullin et al. 2001). It has been assumed that there is a small group that occurs in the near-equatorial waters, a medium-size group that is distributed within the entire distribution range, and a large-size group that occurs at the northern and southern peripheries of its distribution range. However, a high degree of variability in the size of the groupings was observed along the eastern Pacific Ocean (Keyl et al., 2011; Morales-Bojórquez and Pacheco-Bedoya, 2016); for example, the mantle length at first maturity was found to vary between 31.0 to $77.0 \mathrm{~cm}$ off Mexico (Markaida, 2006). Moreover, little genetic diversity has been found among these three groups on the basis of microsatellite loci (Sanchez et al., 2016). In contrast to this hypothetical spatial distribution, other researchers have divided $D$. gigas into northern and southern populations on the basis of genetic structure (Sandoval-Castellanos et al., 2007) or elemental signatures in the statolith (Liu et al., 2015 b). In this study, not only $D$. gigas from northern and southern populations were examined, but also individuals from equatorial central eastern Pacific. For squid whose population structure is uncertain, a holistic management approach should always be considered on the assumption that it is a single population. However, if it can be unequivocally shown that separate stocks are present in the $D$. gigas population, stock-specific harvest strategies may be more effective in providing a sustainable biomass.
In $D$. gigas, the gladius, or pen, is a flexible internal structure that grows from the tail fin toward the head (Fig. 1). Morphologically, the gladius consists of a feather-shaped plate, the proostracum that tapers toward the posterior end of the gladius, becoming a funnel-shaped conus with a smallish rostrum (Arkhipkin et al, 2012). The gladius lies within the shell sac, which attaches to the fin cartilage in the vicinity of the conus and rostrum, whereas, the cartilage attaches to the fin muscles (Young and Vecchione, 1996; Arkhipkin et al, 2012). The gladius is a metabolically inert tissue that grows continuously throughout the lifetime of the species. Previous studies have shown that it is useful in age studies and can reveal ontogenetic patterns associated with changes in diet and habitat (Perez et al., 1996; Ruiz-Cooley et al., 2010; Li et al., 2017). Nonetheless, little attention has been paid to variations in gladius growth although the differences in age, growth, and population structure have often been observed (Sandoval-Castellanos et al., 2007; Chen et al., 2013; Ibáñez et al., 2016).

In this study, the morphometric characteristics of the gladius were analyzed. Our goal was to identify potential sexual dimorphism and spatial variations of gladius shape among population units within $D$. gigas. This study provides an alternative way to identify the potential geographic populations of $D$. gigas and contributes new information on the gladius of Ommastrephidae. 


\section{Materials and methods}

\section{Sampling and preparation}

D. gigas samples were collected during various commercial jigging vessels operating in 2009, 2013, and 2014 in the waters of northern (off the Costa Rica Dome, [CRD]) and southern hemisphere (off the Peru Exclusive Economic Zone, [PE]) and equatorial Pacific Ocean (offshore waters of the central eastern Pacific, [CEP]) (Fig. 2 ). All squid were frozen on board and then transported to the Key Laboratory of Sustainable Exploitation of Oceanic Fisheries Resources at Shanghai Ocean University where they were defrosted under normal room temperature. Dorsal mantle length (ML), fin length (FL), and fin width (FW) were recorded to the nearest $1 \mathrm{~mm}$, and body weight (BW) was measured to the nearest $1 \mathrm{~g}$. Sex and maturity stage were determined on the basis of visual evaluation of the gonad morphometric characteristics defined by Lipiński and Underhill (1995). The gladius was extracted from its dorsomedial site in the mantle cavity and cleaned in an ultrasonic cleaner with distilled water. Gladii which appeared to be damaged were eliminated. Statoliths were extracted for age determination and the number of growth increments were counted under the assumption that the increment is deposited daily (Jackson and Forsythe, 2002).

\section{Morphometric measurements}

A total of 562 gladii from the three regions were used in the subsequent analyses, and detailed information on the samples can be seen in Table 1. Eight morphometric characteristics of the gladius (gladius length [GL], conus length [CL], maximum width of conus [CW], proostracum length [PL], maximum width of prostracum [PW], length from anterior tip of conus to the widest point of proostracum [PWL], length from anterior tip of conus to proximal end of lateral plates [LPL], the width between two anterior apices of lateral plates [LPW]) were measured from each sample to the nearest $1 \mathrm{~mm}$ (Fig. 1). All morphometric measurements were made by a single researcher throughout our study.

\section{Statistical analyses}

All morphometric data used for the analyses of sexual dimorphism and geographic variation were standardized to remove the allometric effects of body size and meet the assumptions of normality. To accomplish this, raw data were transformed by using the following formula (see Lleonart et al., 2000 for details):

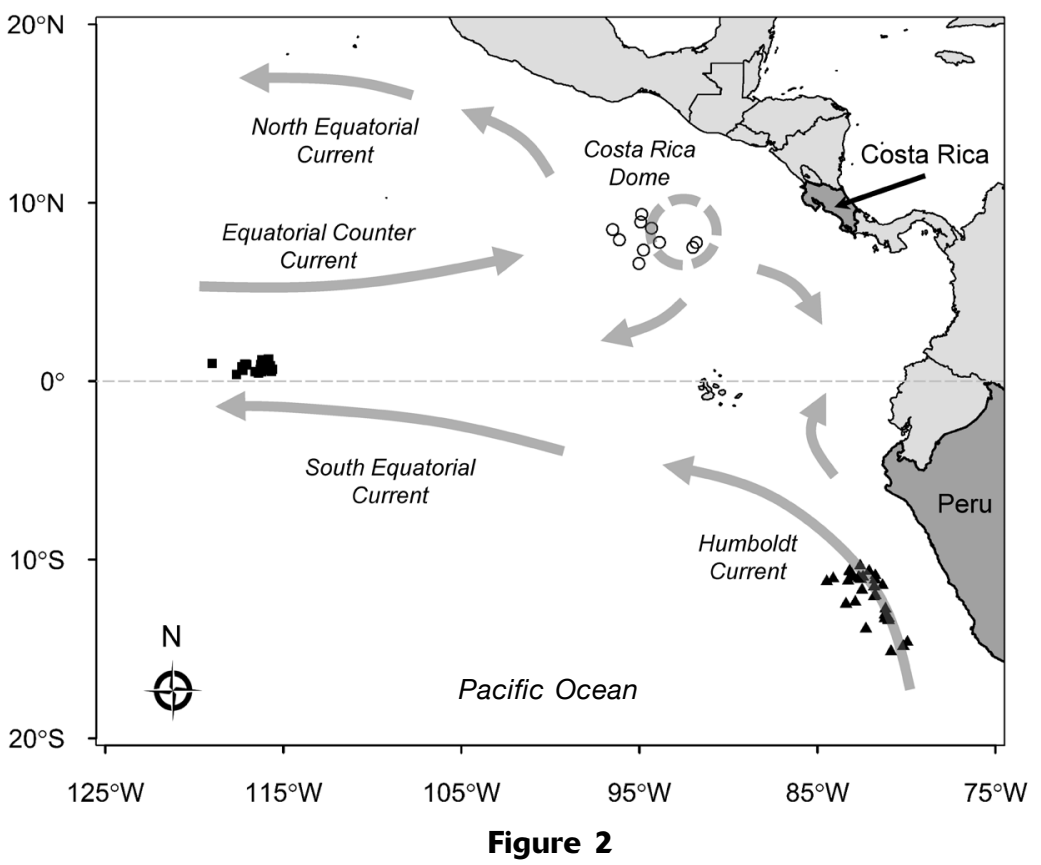

Map of the major surface currents (adapted from Anderson and Rodhouse, 2001) and the locations where jumbo squid (Dosidicus gigas) were sampled in 2009, 2013, and 2014 off the Costa Rica Dome (CRD). Sampling locations off the CRD are indicated with open circles, sampling locations off the Peruvian exclusive economic zone (PE), are indicated with black triangles, and those in offshore waters of the central eastern Pacific (CEP) are indicated with black squares. Morphological features were used to distinguish between populations in different geographic zones

$$
Y_{\mathrm{i}}^{*}=Y_{\mathrm{i}}\left(\frac{M L_{0}}{M L_{\mathrm{i}}}\right)^{\mathrm{b}},
$$

where $Y=$ one of the morphometric variables of the gladius;

$Y_{\mathrm{i}}^{*}=$ the standardized value for the individual $I$; $Y_{\mathrm{i}}$ and $M L_{\mathrm{i}}=$ the observed values of $Y$ and $M L$ for the individual $I$;

$M L_{0}=$ the arithmetic mean for the study population; and

$b$ can be predicted from the following formula:

$$
\ln (Y)=\ln (a)+b \ln (M L)+\varepsilon \varepsilon \sim \mathrm{N}\left(0, \sigma^{2}\right),
$$

where $a=$ a parameter to be estimated; and

$\sigma^{2}=$ the variance for the normally distributed unexplained errors $\varepsilon$.

The standardized variables are represented by subscript "S", i.e. $\mathrm{CL}_{\mathrm{S}}, \mathrm{CW}_{\mathrm{S}}, \mathrm{PL}_{\mathrm{S}}, \mathrm{PW}_{\mathrm{S}}, \mathrm{PWL}_{\mathrm{S}}, \mathrm{LPL}_{\mathrm{S}}$, $\mathrm{LPW}_{\mathrm{S}}, \mathrm{FL}_{\mathrm{S}}$ and $\mathrm{FW}_{\mathrm{S}}$.

One-way analysis of variance (ANOVA) and stepwise discriminant analysis (SDA) were used to analyze sexual dimorphism. The SDA is a method of linear modeling to estimate the proportion of correct classification with a leave-one out stepwise jack-knife procedure. Owing to the small sample size of males, samples from off the CRD was excluded from this analysis. 


\section{Table 1}

Summary information, including mean dorsal mantle length (ML) and body weight (BW) with standard deviations (SDs), for jumbo squid (Dosidicus gigas) sampled in 2009, 2013, and 2014 off the Costa Rica Dome (CRD), off the Peruvian exclusive economic zone (PE), and in offshore waters of the central eastern Pacific (CEP) to examine the use of morphological features to distinguish between populations in different geographic zones. $n=$ number of squid in a sample

\begin{tabular}{|c|c|c|c|c|c|c|c|c|c|c|c|c|}
\hline \multirow[b]{2}{*}{$\begin{array}{l}\text { Geographic } \\
\text { population }\end{array}$} & \multirow[b]{2}{*}{$n(\mathrm{~F}, \mathrm{M})$} & \multirow[b]{2}{*}{$\begin{array}{l}\text { Sampling } \\
\text { date }\end{array}$} & \multirow[b]{2}{*}{ Coordinates } & \multirow[b]{2}{*}{$\begin{array}{l}\text { Maturity } \\
\text { stage }\end{array}$} & \multicolumn{4}{|c|}{$\mathrm{ML}(\mathrm{cm})$} & \multicolumn{4}{|c|}{ BW (g) } \\
\hline & & & & & $\begin{array}{l}\text { Maxi- } \\
\text { mum }\end{array}$ & $\begin{array}{l}\text { Mini- } \\
\text { mum }\end{array}$ & Mean & SD & $\begin{array}{l}\text { Maxi- } \\
\text { mum }\end{array}$ & $\begin{array}{l}\text { Mini- } \\
\text { mum }\end{array}$ & Mean & SD \\
\hline CRD & $\begin{array}{l}105 \\
(89,16)\end{array}$ & $\begin{array}{l}\text { Jul. to } \\
\text { Aug. } 2009\end{array}$ & $\begin{array}{l}91^{\circ} 48^{\prime}-99^{\circ} 30^{\prime} \mathrm{W} \\
6^{\circ} 36^{\prime}-9^{\circ} 30^{\prime} \mathrm{N}\end{array}$ & I-IV & 40.9 & 21.8 & 29.5 & 3.1 & 1907.5 & 252.6 & 737.2 & 256.9 \\
\hline \multirow[t]{3}{*}{$\mathrm{PE}$} & $\begin{array}{l}32 \\
(27,5)\end{array}$ & $\begin{array}{l}\text { Sep. to } \\
\text { Oct. } 2009\end{array}$ & $\begin{array}{l}82^{\circ} 06^{\prime}-84^{\circ} 29^{\prime} \mathrm{W} \\
10^{\circ} 21-11^{\circ} 17^{\prime} \mathrm{S}\end{array}$ & I-III & 44.7 & 26.4 & 32.7 & 4.6 & 2928.7 & 490.0 & 1088.2 & 555.4 \\
\hline & $\begin{array}{l}179 \\
(116,63)\end{array}$ & $\begin{array}{l}\text { Jul. to } \\
\text { Oct. } 2013\end{array}$ & $\begin{array}{l}79^{\circ} 57^{\prime}-83^{\circ} 24^{\prime} \mathrm{W} \\
10^{\circ} 54^{\prime}-15^{\circ} 09^{\prime} \mathrm{S}\end{array}$ & I-IV & 39.6 & 21.8 & 26.8 & 4.3 & 1647.0 & 278.0 & 548.8 & 379.8 \\
\hline & $\begin{array}{l}71 \\
(38,33)\end{array}$ & $\begin{array}{l}\text { Feb. to } \\
\text { Sep. } 2014\end{array}$ & $\begin{array}{l}74^{\circ} 57^{\prime}-83^{\circ} 13^{\prime} \mathrm{W} \\
10^{\circ} 26^{\prime}-22^{\circ} 38^{\prime} \mathrm{S}\end{array}$ & I-IV & 48.5 & 19.1 & 28.1 & 7.3 & 3361.0 & 177.0 & 767.9 & 721.4 \\
\hline \multirow[t]{2}{*}{ CEP } & $\begin{array}{l}121 \\
(57,64)\end{array}$ & $\begin{array}{l}\text { Apr. to } \\
\text { Jun. } 2013\end{array}$ & $\begin{array}{l}114^{\circ} 59^{\prime}-119^{\circ} 00^{\prime} \mathrm{W} \\
0^{\circ} 28^{\prime} \mathrm{N}-1^{\circ} 00^{\prime} \mathrm{S}\end{array}$ & I-IV & 37.2 & 22.2 & 29.2 & 3.7 & 1523.0 & 291.0 & 746.7 & 300.7 \\
\hline & $\begin{array}{l}54 \\
(45,9)\end{array}$ & $\begin{array}{l}\text { Apr. to } \\
\text { May. } 2014\end{array}$ & $\begin{array}{l}116^{\circ} 00^{\prime}-117^{\circ} 19^{\prime} \mathrm{W} \\
0^{\circ} 42^{\prime}-0^{\circ} 58^{\prime} \mathrm{N}\end{array}$ & I-III & 41.2 & 27.5 & 33.0 & 3.0 & 1849.0 & 608.0 & 1059.8 & 300.9 \\
\hline
\end{tabular}

Principal component analysis (PCA) was used to determine the main morphometric variables among three population units by reducing the multidimensional data. SDA was performed on the results of PCA to identify the variables that would distinguish the geographic populations and calculate the classification rates.

Moreover, to remove the potential impacts of the disproportionate number of female $D$. gigas and different sex ratios for the three sites, PCA and SDA were repeated with female data only as an independent data set to evaluate the geographic divergence of females.

The analyses of growth rates were performed on untransformed morphometric and age data. The absolute daily growth rate (DGR, $\mathrm{mm} /$ day) was calculated for each 25-day interval with the following equation (Forsythe and Van Heukelem, 1987):

$$
D G R=\frac{L_{2}-L_{1}}{t_{2}-t_{1}},
$$

where $L=$ one of the morphometric variables of the gladius;

$L_{1}$ and $L_{2}=$ the observed values $(\mathrm{mm})$ at the beginning $\left(t_{1}\right)$ and the end $\left(t_{2}\right)$ of each interval of time (day).

Multiple comparison was examined by using ANOVA with post-hoc Tukey's honestly significant difference (HSD) test. For nonnormal and ordinal data, a matched comparison with the Friedman test was applied. A $P$ value of $\leq 0.05$ was considered significant for all statis- tical tests, and statistical analyses were carried out by SPSS Statistics, ${ }^{1}$ vers. 19.0 (IBM Corp., Armonk, NY).

\section{Results}

\section{Gladius structure}

Morphometric variables of the three geographic populations are presented in the Supplementary Table.

Regression analysis performed on the GL and ML showed strong correlations within the three geographic populations (CRD: $r=0.95, \mathrm{ML}=1.005 \mathrm{GL}+1.267$; $\mathrm{PE}: \quad r=0.98, \quad \mathrm{ML}=0.94 \mathrm{GL}+0.99 ; \quad \mathrm{CEP}: \quad r=0.99$, $\mathrm{ML}=1.03 \mathrm{GL}-0.63)$. As main morphological parts of the gladius, the ratio of CL to $\mathrm{PL}(\mathrm{CL} / \mathrm{PL})$ showed significant differences (ANOVA, $P<0.05, F_{2,558}=87.30$ ) among regions. The $\mathrm{CL} / \mathrm{PL}$ values for squid off the CRD $(0.22$ $\pm 0.02)$ were lower than those off the PE $(0.24 \pm 0.02)$ and CEP squid (0.26 \pm 0.02$)$. In addition, the CL showed significant positive relationships with FW (CR: $r=0.77$; PE: $r=0.90$; CEP: $r=0.70)$ and FL (CR: $r=0.82$; $\mathrm{PE}: r=0.89$; CEP: $r=0.72$ ).

\section{Sexual dimorphism}

When comparing morphometric characteristics between females and males, we found that only $\mathrm{CL}_{\mathrm{S}}, \mathrm{CW}_{\mathrm{S}}$ and

\footnotetext{
${ }^{1}$ Mention of trade names or commercial companies is for identification purposes only and does not imply endorsement by the National Marine Fisheries Service, NOAA.
} 


\section{Table 2}

Results of analysis of variance between sexes for standardized $(\mathrm{s})$ gladius morphometric variables of jumbo squid (Dosidicus gigas) sampled in 2009, 2013, and 2014 off the Peruvian exclusive economic zone (PE) and in offshore waters of the central eastern Pacific (CEP). The morphometric variables are conus length (CL), maximum width of conus $(\mathrm{CW})$, proostracum length $(\mathrm{PL})$, maximum width of prostracum (PW), length from anterior tip of conus to the widest point of proostracum (PWL), length from anterior tip of conus to proximal end of lateral plates (LPL), and width between 2 anterior apices of lateral plates (LPW). $n=$ number of samples; $F=$ variance between the means of female and male values; ns $=$ nonsignificant, probability $(P)>0.05 ; *=P<0.05$; $* *=P<0.01$

\begin{tabular}{|c|c|c|c|c|}
\hline \multirow[b]{2}{*}{ Variable } & \multicolumn{2}{|c|}{$\mathrm{PE}$} & \multicolumn{2}{|c|}{ CEP } \\
\hline & $F$ & $P$ & $F$ & $P$ \\
\hline$n$ & \multicolumn{2}{|c|}{282} & \multicolumn{2}{|c|}{175} \\
\hline $\mathrm{CL}_{\mathrm{S}}$ & 3.72 & $\mathrm{~ns}$ & 38.67 & $* *$ \\
\hline $\mathrm{CW}_{\mathrm{S}}$ & 2.40 & $\mathrm{~ns}$ & 27.06 & $* *$ \\
\hline $\mathrm{PL}_{\mathrm{S}}{ }^{\mathrm{B}}$ & 8.21 & $* *$ & 281.11 & $* *$ \\
\hline $\mathrm{PW}_{\mathrm{S}}$ & 5.93 & $*$ & 89.90 & $* *$ \\
\hline $\mathrm{PWL}_{\mathrm{S}}$ & 26.29 & $* *$ & 57.87 & $* *$ \\
\hline $\mathrm{LPL}_{\mathrm{S}}$ & 3.07 & $\mathrm{~ns}$ & 78.39 & $* *$ \\
\hline $\mathrm{LPW}_{\mathrm{S}}$ & 4.34 & $*$ & 60.13 & $* *$ \\
\hline
\end{tabular}

$\mathrm{LPL}_{\mathrm{S}}$ of PE specimens were not different for the sexes (Table 2). Meanwhile, the SDA results showed that the correct cross-validated classification rates reached from $62.4 \%$ to $94.3 \%$ for the region off $\mathrm{PE}$ and within the CEP, respectively (Table 3 ). The results may indicate a significant difference between the sexes within each population.

\section{Geographic variations}

For all individuals, the PCA of the morphometric features of squid gladii retained two principal components (PC1 and PC2), having eigenvalues greater than 1 and accounted for $62.40 \%$ and $14.81 \%$ of the total variance, respectively. The main variables counting for variation in $\mathrm{PC} 1$ were $\mathrm{CL}_{\mathrm{S}}, \mathrm{PL}_{\mathrm{S}}, \mathrm{PW}_{\mathrm{S}}, \mathrm{PWL}_{\mathrm{S}}, \mathrm{LPL}_{\mathrm{S}}$, and $\mathrm{LPW}_{\mathrm{S}}$. Variation of PC2 was mainly influenced by $\mathrm{CW}_{\mathrm{S}}$. The SDA performed on all samples identified four valid gladius morphometric features $\left(\mathrm{CL}_{\mathrm{S}}, \mathrm{CW}_{\mathrm{S}}, \mathrm{PL}_{\mathrm{S}}\right.$ and $\mathrm{PW}_{\mathrm{S}}$ ) that served as discriminatory variables for the three geographic populations (Table 4). The first canonical function explained $83.9 \%$ of the total variance. Although there was considerable overlap, the final correct cross-validated classification rates among the geographic populations reached $80.0 \%$ (off the CRD), 74.8\% (off the PE) and 84.0\% (within the CEP), respectively (Table 5A).

The PCA performed on data sets for females detected only one principal component with eigenvalues greater

\section{Table 3}

The percentages of cross-validated classification from stepwise discriminant analysis for each sex of 2 geographic populations of jumbo squid (Dosidicus gigas) sampled in 2013 and 2014 off the Peruvian exclusive economic zone (PE) and in offshore waters of the central eastern Pacific (CEP).

\begin{tabular}{lcclcc}
\hline & \multicolumn{2}{c}{$\mathrm{PE}$} & & \multicolumn{2}{c}{ CEP } \\
\cline { 2 - 3 } \cline { 5 - 6 } & Female & Male & & Female & Male \\
\hline Female & $62.0 \%$ & $38.0 \%$ & & $96.1 \%$ & $3.9 \%$ \\
Male & $36.7 \%$ & $63.3 \%$ & & $8.2 \%$ & $91.8 \%$ \\
Total & \multicolumn{2}{c}{$62.4 \%$} & & \multicolumn{2}{c}{$94.3 \%$} \\
$P$ & $<0.001$ & & \multicolumn{2}{c}{$<0.001$} \\
& & & & \\
\hline
\end{tabular}

than 1 and explaining $65.30 \%$ of the total variance. All morphometric features showed high contributions to the principal component analysis. The SDA selected $\mathrm{CL}_{\mathrm{S}}, \mathrm{CW}_{\mathrm{S}}, \mathrm{PL}_{\mathrm{S}}$, and $\mathrm{PW}_{\mathrm{S}}$ as suitable variables to distinguish female $D$. gigas from the three regions, with a misclassification rate of $16.8 \%$ (Tables 4 and 5B).

A total of 340 statoliths from the three sites were satisfactorily prepared for age determination. In all three population units, values of DGR for PL were larger than CL during all studied periods for each sex (Friedman test, $P<0.01$, Table 6), although small sample sizes may have influenced the reliability of calculated growth rates in some age groups.

For each geographic population, the maximum DGR in CL was found from 201 to 225 days of age for female D. gigas (Table 6). Although the maximum DGR in PL occurred at different periods, the value for off the CRD (1.44 $\mathrm{mm} / \mathrm{d}, 201-225$ days) and off the PE $(1.12 \mathrm{~mm} / \mathrm{d}$, 201-225 days) were larger but occurred later than the CEP value $(1.11 \mathrm{~mm} / \mathrm{d}, 176-200$ days $)$. For males, the maximum DGR in CL $(0.41 \mathrm{~mm} / \mathrm{d})$ was reached from 201to 225 days of age for PE, wheras in the CEP the maximum is smaller $(0.34 \mathrm{~mm} / \mathrm{d})$ and it is reached before, at 176-200 days. In contrast, the maximum DGR in PL was observed at 201-225 and 176-200 days for males off the PE and within the CEP (Table 6).

\section{Discussion}

\section{Gladius structure}

In $D$. gigas, a strong correlation was found between GL and ML in each geographic population. This finding indicates that the gladius can be considered a hard tissue that supports the mantle and internal organs. Similar results were reported for other ommastrephids, Illex illecebrosus (Perez et al., 1996) and Ommastrephes bartramii (Kato et al., 2016). Also, GL may be a more reliable measurement than $\mathrm{ML}$ when individuals are 


\begin{tabular}{|c|c|c|c|c|}
\hline \multicolumn{5}{|c|}{ Table 4} \\
\hline \multicolumn{5}{|c|}{$\begin{array}{l}\text { Function coefficients for } 3 \text { geographic populations of jumbo squid (Dosi- } \\
\text { dicus gigas) sampled off the Costa Rica Dome (CRD), off the Peruvian } \\
\text { exclusive economic zone (PE), and offshore waters of the central eastern } \\
\text { Pacific (CEP) in } 2009,2013 \text {, and } 2014 \text {. The morphometric features used } \\
\text { for the examination are proostracum length (PL), conus length (CL), the } \\
\text { maximum width of conus (CW), and the maximum width of prostracum } \\
\text { (PW). }\end{array}$} \\
\hline & & CR & $\mathrm{PE}$ & CEP \\
\hline \multirow[t]{5}{*}{ All individuals } & $\mathrm{PL}_{\mathrm{S}}$ & 19.56 & 20.17 & 23.78 \\
\hline & $\mathrm{CL}_{\mathrm{S}}$ & 12.02 & 18.08 & 25.72 \\
\hline & $\mathrm{CW}_{\mathrm{S}}$ & 31.57 & 29.65 & 32.15 \\
\hline & $\mathrm{PW}_{\mathrm{S}}$ & -37.22 & -31.43 & -37.54 \\
\hline & (constant) & -392.63 & -365.74 & -441.60 \\
\hline \multirow[t]{5}{*}{ Females } & $\mathrm{PL}_{\mathrm{S}}$ & 25.07 & 25.63 & 30.48 \\
\hline & $\mathrm{CL}_{\mathrm{S}}$ & 42.88 & 47.98 & 62.08 \\
\hline & $\mathrm{CW}_{\mathrm{S}}$ & 40.57 & 38.26 & 42.58 \\
\hline & $\mathrm{PW}_{\mathrm{S}}$ & -26.65 & -18.64 & -25.87 \\
\hline & (constant) & -532.33 & -498.69 & -629.86 \\
\hline
\end{tabular}

stored frozen because soft tissues can be deformed during the thawing process. In this study, positive correlations were found between the CL with FL and FW in all three population units. The conus, which is located in the middle of the tail fin, is the main morphological section of the gladius (Arkhipkin et al., 2012). With their anatomical analysis, Young and Vecchione (1996) found that fin cartilage connected the fin muscles and shell sac, which secretes the conus and cone flags. Therefore, the conus could be considered a supporting structure that helps the fin resist the dynamic pressures generated during swimming (Bizikov and Arkhipkin, 1997; Arkhipkin et al., 2012). A longer conus might also provide appropriate support for the fin when the animal is experiencing high speed currents.

\section{Sexual size dimorphism}

Sexual size dimorphism is a common phenomenon that occurs in the hard structures of cephalopods (Fang et al., 2014; Liu et al., 2015a). Our results also showed that the shapes of gladii were different for the sexes within two of the populations (i.e., off the PE and within the CEP). These results are in agreement with those from Liu et al. (2015a) who observed sexual dimorphism in another hard structure, the beak of $D$. gigas, from these same two populations which are found in the waters off Peru and Ecuador, termed PE and CEP, respectively in our study. This difference in shapes was despite the fact that both populations experienced similar environmental conditions and food availability. However, sex-specific different nutritional requirements have recently been described for female and male squid and may explain the sexual dimorphism we observed (e.g. Nototodarus gouldi, (Steer and Jackson, 2004), Sepioteuthis australis (Pecl and Moltschaniwskyj, 2006) and Illex argentines (Lin et al., 2015)). In these cases, females and males within the population show divergent energetic needs for growth or reproduction, and one might expect this to result in squid with different growth-related parameters, which could have a potential impact on the gladius morphometric characteristics (van der Vyver et al., 2016). Additionally, there may be sexually related behavioral differences where females and males might forage on different prey items at different depths in a given habitat (Arkhipkin and Middleton, 2002).

\section{Geographic variations}

Dosidicus gigas is a species endemic to the eastern Pacific and has a complex population structure. Geographic variations in age, growth, and reproduction of this species have often been observed (Sandoval-Castellanos et al., 2007; Chen et al., 2013; Ibáñez et al., 2016). As reported by Liu et al. (2015a), spatial variations in the beak structure of $D$. gigas could be used to distinguish geographic populations. This difference was attributed to a phenotypic response resulting from distinct environmental conditions that a population experiences at a given geographic location (Liu et al., 2015a; van der Vyver et al., 2016), but further research is needed to confirm the exact relationship between a species' physiological response to variations in the environment.

In this study, the SDA revealed a high rate of correct classification of gladii shapes among geographic populations, even with the female data as an independent data set (Table 5B). When looking at the environmental conditions these populations experience, 


\section{Table 5}

Results of the stepwise procedure of discriminant analysis showing the order of standardized $(\mathrm{s})$ morphometric variables to entry for $(\mathbf{A}) 3$ geographic populations and (B) the female jumbo squid (Dosidicus gigas) sampled in 2009, 2013, and 2014 off the Costa Rica Dome (CRD), off the Peruvian exclusive economic zone (PE), and in offshore waters of the central eastern Pacific (CEP). Correct cross-validated classification rates are shown in bold type. The morphometric variables are proostracum length (PL), conus length (CL), the maximum width of conus (CW), and the maximum width of prostracum (PW). At each step, the variable with the largest $F$ value that exceeds the entry criteria is added.

$\mathbf{A}$

\begin{tabular}{lccccc}
\hline Step no. & Variable & $F$ & df 1 & df 2 & $P$ \\
\hline 1 & $\mathrm{PL}_{\mathrm{S}}$ & 264.60 & 2 & 559.00 & $<0.01$ \\
2 & $\mathrm{CL}_{\mathrm{S}}$ & 193.95 & 4 & 1116.00 & $<0.01$ \\
3 & $\mathrm{CW}_{\mathrm{S}}$ & 151.85 & 6 & 1114.00 & $<0.01$ \\
4 & $\mathrm{PW}_{\mathrm{S}}$ & 119.01 & 8 & 1112.00 & $<0.01$ \\
\hline
\end{tabular}

Number and percentage of samples classified to a population

\begin{tabular}{|c|c|c|c|c|}
\hline \multirow[b]{2}{*}{ Population } & & \multirow[b]{2}{*}{ Total } \\
\hline & $\mathrm{CR}$ & $\mathrm{PE}$ & CEP & \\
\hline CR & 84 & 18 & 3 & 105 \\
\hline$\%$ & 80.0 & 17.1 & 2.9 & 100 \\
\hline $\mathrm{PE}$ & 62 & 211 & 9 & 282 \\
\hline$\%$ & 22.0 & 74.8 & 3.2 & 100 \\
\hline CEP & 14 & 14 & 147 & 175 \\
\hline \multirow[t]{2}{*}{$\%$} & 8.0 & 8.0 & 84.0 & 100 \\
\hline & & & Total correct $(\%)$ & 78.6 \\
\hline
\end{tabular}

B

\begin{tabular}{lccccc}
\hline Step no. & Variable & $F$ & df 1 & df 2 & $P$ \\
\hline 1 & PLs & 331.32 & 2 & 372.00 & $<0.01$ \\
2 & CLs & 204.84 & 4 & 742.00 & $<0.01$ \\
3 & CWs & 165.34 & 6 & 740.00 & $<0.01$ \\
4 & PWs & 129.74 & 8 & 738.00 & $<0.01$ \\
\hline
\end{tabular}

Number and percentage of samples classified to a population

\begin{tabular}{lcccc}
\cline { 2 - 4 } Population & CR & PE & CEP & Total \\
\hline CR & 72 & 14 & 3 & 89 \\
$\%$ & $\mathbf{8 0 . 9}$ & 15.7 & 3.4 & 100 \\
PE & 39 & 141 & 4 & 184 \\
$\%$ & 21.2 & $\mathbf{7 6 . 6}$ & 2.2 & 100 \\
CEP & 3 & 0 & 99 & 102 \\
$\%$ & 2.9 & 0 & $\mathbf{9 7 . 1}$ & 100 \\
& & & Total correct $(\%)$ & $\mathbf{8 3 . 2}$
\end{tabular}

there is reason to believe that our SDA results can be explained by these environmental differences. For example, the Costa Rica Dome (Fig. 2) is an oceanic upwelling center where the thermocline is shallow (Sasai et al., 2007), whereas the waters off Peru (PE) are primarily affected by the cold northward flowing Humboldt Current and are associated with strong upwelling of cool subsurface waters (Chavez et al., 2008).
Individuals in the CEP were from an area primarily influenced by a warm Equatorial Counter Current and the cooler South Equatorial Current (Fig. 2). The differences in oceanographic conditions in each region may consequently result in morphometric variations in the gladius. For example, several studies have shown that ambient temperature has a significant influence on the growth and development of D. gigas (Keyl et al., 


\section{Table 6}

Absolute daily growth rates (DGR) in mm/day for conus length (CL) and proostracum lengh (PL) for female and male jumbo squid (Dosidicus gigas) sampled off the Costa Rica Dome (CRD), off the Peruvian exclusive economic zone (PE), and in offshore waters of the central eastern Pacific (CEP) in 2009, 2013, and 2014. $n=$ number of squid in a sample. na=data not available.

\begin{tabular}{|c|c|c|c|c|c|c|c|}
\hline Population & Sex & $\begin{array}{l}\text { Age class } \\
\text { (d) }\end{array}$ & $n$ & $\begin{array}{l}\text { Average } \\
\text { CL (mm) }\end{array}$ & $\begin{array}{c}\text { DGR } \\
(\mathrm{mm} / \mathrm{d})\end{array}$ & $\begin{array}{l}\text { Average } \\
\text { PL (mm) }\end{array}$ & $\begin{array}{l}\text { DGR } \\
(\mathrm{mm} / \mathrm{d})\end{array}$ \\
\hline \multirow[t]{5}{*}{$\mathrm{CR}$} & \multirow[t]{5}{*}{$\mathrm{F}$} & $126-150$ & 2 & 37.5 & na & 167.5 & na \\
\hline & & $151-175$ & 15 & 43.1 & 0.22 & 198.0 & 1.22 \\
\hline & & $176-200$ & 36 & 49.2 & 0.24 & 222.9 & 1.00 \\
\hline & & $201-225$ & 29 & 57.9 & 0.35 & 259.0 & 1.44 \\
\hline & & $226-250$ & 3 & 63.0 & 0.20 & 288.0 & 1.16 \\
\hline \multirow[t]{10}{*}{$\mathrm{PE}$} & \multirow[t]{6}{*}{$\mathrm{F}$} & $126-150$ & 8 & 46.0 & na & 188.0 & na \\
\hline & & $151-175$ & 31 & 49.2 & 0.13 & 200.6 & 0.50 \\
\hline & & $176-200$ & 41 & 51.9 & 0.11 & 211.0 & 0.42 \\
\hline & & $201-225$ & 7 & 62.1 & 0.41 & 239.0 & 1.12 \\
\hline & & $226-250$ & 2 & 68.5 & 0.26 & 255.5 & 0.66 \\
\hline & & $251-275$ & 2 & 78.0 & 0.38 & 278.5 & 0.92 \\
\hline & \multirow[t]{4}{*}{ M } & $126-150$ & 6 & 42.5 & na & 186.3 & na \\
\hline & & $151-175$ & 17 & 47.3 & 0.19 & 194.8 & 0.34 \\
\hline & & $176-200$ & 21 & 49.8 & 0.10 & 204.2 & 0.38 \\
\hline & & $201-225$ & 8 & 60.1 & 0.41 & 233.4 & 1.17 \\
\hline \multirow[t]{10}{*}{ CEP } & \multirow[t]{5}{*}{$\mathrm{F}$} & $126-150$ & 5 & 50.6 & na & 191.6 & na \\
\hline & & $151-175$ & 6 & 54.7 & 0.16 & 208.3 & 0.67 \\
\hline & & $176-200$ & 26 & 59.7 & 0.20 & 236.0 & 1.11 \\
\hline & & $201-225$ & 12 & 65.8 & 0.24 & 250.7 & 0.59 \\
\hline & & $226-250$ & 4 & 69.5 & 0.15 & 276.0 & 1.01 \\
\hline & \multirow[t]{5}{*}{ M } & $126-150$ & 5 & 45.8 & na & 185.0 & na \\
\hline & & $151-175$ & 13 & 51.6 & 0.23 & 200.5 & 0.62 \\
\hline & & $176-200$ & 27 & 60.1 & 0.34 & 234.7 & 1.37 \\
\hline & & $201-225$ & 13 & 64.5 & 0.18 & 252.50 & 0.71 \\
\hline & & $226-250$ & 1 & 67.0 & 0.10 & 268.00 & 0.62 \\
\hline
\end{tabular}

2011; Staaf et al., 2011). The proostracum contributes to a large proportion of GL $(>80 \%)$ and has a higher longitudinal growth rate than conus (Table 6). With the assumption that the conus provides a supporting structure for the fin during swimming, the higher growth rate of the proostracum can be considered a structure that meets the requirements for rapid growth of squids because the gladius is a tissue that supports the growth of the mantle and internal organs (Bizikov and Arkhipkin, 1997; Arkhipkin et al., 2012). Comparisons in $\mathrm{CL} / \mathrm{PL}$ values and growth rates between geographic populations show spatial variations in these two structures. The squid from CEP had higher CL/PL values than the squid from the area of the CRD and PE. We suggest that this result is possibly due to the environmental conditions experienced by the squid off the CRD and $\mathrm{PE}$ that are reflected in the longitudinal growth of proostracum. The Humboldt Current or upwelling (or both) supply nutrients to the waters off Peru and the CRD, while the waters of the central equatorial Pacific have lower primary productivity (Anderson and Rodhouse, 2001; Fiedler, 2002). Because food availability is considered as one of the central factors that influences D. gigas growth (Chen et al., 2013; Liu et al., 2013), regional differences in primary productivity may be strongly correlated with the observed differences in the growth of gladius.

Although the squid populations can be distinguished on the basis of morphological evidence, there is still considerable overlap, as shown in Table 5, A and B, which suggests that stable population substructuring is not the norm. Similar overlap has also been observed in elemental signatures in statoliths o $D$. gigas from waters off the Costa Rica Dome and Peru (Liu et al., $2015 b)$. Indeed it was reported that a weak northern and southern hemisphere divergence was found for $D$. gigas with the use of molecular methods. SandovalCastellanos et al. (2010) and Staaf et al. (2010), and some of our results from CEP individuals have also indicated a close similarity to the other two jumbo squid populations. This finding would suggest that although the morphological studies reported here suggest clear spatial subpopulations, further research will reveal the stability of these populations units over time. 


\section{Acknowledgments}

We thank observers who helped us with the collection and processing of samples. We also thank B. L. Liu, for providing the squid age data. Y. Gong and Y. K. Li were supported by the National Natural Science Foundation of China (\#41541042), the Natural Science Foundation of Shanghai (\#17ZR1413000), and the Shanghai Leading Academic Discipline Project (Fisheries Discipline). The senior author and $\mathrm{X}$. Chen contributed equally to this work.

\section{Literature cited}

Alegre, A., F. Ménard, R. Tafur, P. Espinoza, J. Argüelles, V. Maehara, O. Flores, M. Simier, and A. Bertrand.

2014. Comprehensive model of jumbo squid Dosidicus gigas trophic ecology in the northern Humboldt Current System. PLoS ONE 9(1):e85919. Article

Anderson, C.I. and P. G. Rodhouse.

2001. Life cycles, oceanography and variability: ommastrephid squid in variable oceanographic environments. Fish. Res. 54:133-143. Article

Arkhipkin, A.I., and D. A. J. Middleton.

2002. Sexual segregation in ontogenetic migrations by the squid Loligo gahi around the Falkland Islands. Bull. Mar. Sci. 71:109-127.

Arkhipkin, A. I., V. A. Bizikov, and D. Fuchs.

2012. Vestigial phragmocone in the gladius points to a deepwater origin of squid (Mollusca: Cephalopoda). Deep-Sea Res., I. 61:109-122. Article

Arkhipkin, A., J. Argüelles, Z. Shcherbich, and C. Yamashiro.

2015. Ambient temperature influences adult size and life span in jumbo squid (Dosidicus gigas). Can. J. Fish. Aquat. Sci. 72:400-409. Article

Bizikov, V. A. and A. I. Arkhipkin.

1997. Morphology and microstructure of the gladius and statolith from the boreal Pacific giant squid Moroteuthis robusta (Oegopsida; Onychoteuthidae). J. Zool. 241: 475-492. Article

Chavez, F. P., A. Bertrand, R. Guevara-Carrasco, P. Soler, and J. Csirke.

2008. The northern Humboldt Current System: brief history, present status and a view towards the future. Prog. Oceanogr. 79:95-105. Article

Chen, X., J. Li, B. Liu, Y. Chen, G. Li, Z. Fang, and S. Tian. 2013. Age, growth and population structure of jumbo flying squid, Dosidicus gigas, off the Costa Rica Dome. J. Mar. Biol. Assoc. U.K. 93:567-573. Article

Crespi-Abril, A. C., E. M. Morsan, and P. J. Barón.

2010. Analysis of the ontogenetic variation in body and beak shape of the Illex argentinus inner shelf spawning groups by geometric morphometrics. J. Mar. Biol. Assoc. U.K. 90:547-553. Article

Fang, Z., B. Liu, J. Li, H. Su, and X. Chen.

2014. Stock identification of neon flying squid (Ommastrephes bartramii) in the North Pacific Ocean on the basis of beak and statolith morphology. Sci. Mar. 78:239248. Article

FAO (Food and Agricultural Organization of the United Nations).

2016. FAO yearbook. Fishery and aquaculture statistics 2014, 78 p. FAO, Rome.
Fiedler, P. C.

2002. The annual cycle and biological effects of the Costa Rica Dome. Deep-Sea Res., I. 49:321-338. Article

Field, J. C., K. Baltz, A. J. Phillips, and W. A. Walker.

2007. Range expansion and trophic interactions of the jumbo squid, Dosidicus gigas, in the California Current. CalCOFI Rep. 48:131-146.

Forsythe, J. W. and W. F. Van Heukelem.

1987. Growth. In Cephalopod life cycles. Vol. II: Comparative reviews (P. R. Boyle, ed.), p. 135-156. Academic Press, London.

Ibáñez, C. M. and L. A. Cubillos.

2007. Seasonal variation in the length structure and reproductive condition of the jumbo squid Dosidicus gigas (d'Orbigny, 1835) off central-south Chile. Sci. Mar. 71:123-128. Article

Ibáñez, C.M., J. Argüelles, C. Yamashiro, R. D. Sepúlveda, M. C. Pardo-Gandarillas, and F. Keyl.

2016. Population dynamics of the squids Dosidicus gigas (Oegopsida: Ommastrephidae) and Doryteuthis gahi (Myopsida: Loliginidae) in northern Peru. Fish. Res. 173:151-158. Article

Jackson, G. D., and J. W. Forsythe.

2002. Statolith age validation and growth of Loligo plei (Cephalopoda: Loliginidae) in the north-west Gulf of Mexico during spring/summer. J. Mar. Biol. Assoc. U.K. 82:677-678. Article

Kato, Y., M. Sakai, H. Nishikawa, H. Igarashi, Y. Ishikawa, D. Vijai, Y. Sakurai, T. Wakabayshi, and T. Awaji.

2016. Stable isotope analysis of the gladius to investigate migration and trophic patterns of the neon flying squid (Ommastrephes bartramii). Fish. Res. 173:169-174. Article

Keyl, F., J. Argüelles, and R. Tafur.

2011. Interannual variability in size structure, age, and growth of jumbo squid (Dosidicus gigas) assessed by modal progression analysis. ICES J. Mar. Sci. 68:507518. Article

Li, Y., Y. Gong, Y. Zhang, and X. Chen.

2017. Inter-annual variability in trophic patterns of jumbo squid (Dosidicus gigas) off the exclusive economic zone of Peru, implications from stable isotope values in gladius. Fish. Res. 187:22-30. Article

Lin, D., X. Chen, Y. Chen, and Z. Fang.

2015. Sex-specific reproductive investment of summer spawners of Illex argentinus in the southwest Atlantic. Invertebr. Biol. 134:203-213. Article

Lipiński, M. R., and L. G. Underhill.

1995. Sexual maturation in squid: quantum or continuum? S. Afr. J. Mar. Sci. 15:207-223. Article

Liu, B., X. Chen, Y. Chen, S. Tian, J. Li, Z. Fang, and M. Yang.

2013. Age, maturation, and population structure of the Humboldt squid Dosidicus gigas off the Peruvian Exclusive Economic Zones. Chin. J. Oceanol. Limnol. 31:81-91. Article

Liu, B., Z. Fang, X. Chen, and Y. Chen.

2015a. Spatial variations in beak structure to identify potentially geographic populations of Dosidicus gigas in the Eastern Pacific Ocean. Fish. Res. 164:185-192. Article

Liu, B. L., Y. Chen, and X. J. Chen.

2015b. Spatial difference in elemental signatures within early ontogenetic statolith for identifying jumbo flying squid natal origins. Fish. Oceanogr. 24:335-346. Article 
Lleonart, J., J. Salat, and G. J. Torres.

2000. Removing allometric effects of body size in morphological analysis. J. Theor. Biol. 205:85-93. Article

Lorrain, A., J. Arguelles, A. Alegre, A. Bertrand, J. M. Munaron, P. Richard, and Y. Cherel.

2011. Sequential isotopic signature along gladius highlights contrasted individual foraging strategies of jumbo squid (Dosidicus gigas). PLoS ONE 6(7):e22194. Article.

Markaida, U.

2006. Population structure and reproductive biology of jumbo squid Dosidicus gigas from the Gulf of California after the 1997-1998 El Niño event. Fish. Res. 79:28-37. Article

Morales-Bojórquez, E. and J. L. Pacheco-Bedoya.

2016. Population dynamics of jumbo squid Dosidicus gigas in Pacific Ecuadorian waters. J. Shellfish Res. 35:211-224. Article

Nesis, K. N.

1993. Population structure of oceanic ommastrephids, with particular reference to Sthenoteuthis oualaniensis: a review. In Recent advances in cephalopod fisheries biology (T. Okutani, R. K. O'Dor, and T. Kubodera, eds.), p. 375-383. Tokai Univ. Press, Tokyo, Japan.

Nigmatullin, C.M., K. N. Nesis, and A. I. Arkhipkin.

2001. A review of the biology of the jumbo squid Dosidicus gigas (Cephalopoda: Ommastrephidae). Fish. Res. 54:9-19. Article

Pecl, G.T., and N. A. Moltschaniwskyj.

2006. Life history of a short-lived squid (Sepioteuthis australis): resource allocation as a function of size, growth, maturation, and hatching season. ICES. J. Mar. Sci. 63:995-1004. Article

Perez, J. A. A., R. K. O’Dor, P. Beck, and E. G. Dawe.

1996. Evaluation of gladius dorsal surface structure for age and growth studies of the short-finned squid, Illex illecebrosus (Teuthoidea: Ommastrephidae). Can. J. Fish. Aquat. Sci. 53:2837-2846. Article

Ruiz-Cooley, R.I., E. C. Villa, and W. R. Gould.

2010. Ontogenetic variation of $\delta^{13} \mathrm{C}$ and $\delta^{15} \mathrm{~N}$ recorded in the gladius of the jumbo squid Dosidicus gigas: geographic differences. Mar. Ecol. Prog. Ser. 399:187-198. Article
Sanchez, G., S. Tomano, C. Yamashiro, R. Fujita, T. Wakabayashi, M. Sakai, and T. Umino.

2016. Population genetics of the jumbo squid Dosidicus gigas (Cephalopoda: Ommastrephidae) in the northern Humboldt Current system based on mitochondrial and microsatellite DNA markers. Fish. Res. 175:1-9. Article

Sandoval-Castellanos, E., M. Uribe-Alcocer, and P. DíazJaimes.

2007. Population genetic structure of jumbo squid (Dosidicus gigas) evaluated by RAPD analysis. Fish. Res. 83:113-118. Article

2010. Population genetic structure of the Humboldt squid (Dosidicus gigas d'Orbigny, 1835) inferred by mitochondrial DNA analysis. J. Exp. Mar. Biol. Ecol. 385:73-78. Article

Sasai, Y., H. Sasaki, K. Sasaoka, A. Ishida, and Y. Yamanaka. 2007. Marine ecosystem simulation in the eastern tropical Pacific with a global eddy resolving coupled physical-biological model. Geophys. Res. Lett. 34:208-219. Article

Staaf, D. J., R. I. Ruiz-Cooley, C. Elliger, Z. Lebaric, B. Campos, U. Markaida, and W. F. Gilly.

2010. Ommastrephid squids Sthenoteuthis oualaniensis and Dosidicus gigas in the eastern Pacific show convergent biogeographic breaks but contrasting population structures. Mar. Ecol. Prog. Ser. 418:165-178. Article

Staaf, D. J., L. D. Zeidberg, and W. F. Gilly.

2011. Effects of temperature on embryonic development of the Humboldt squid Dosidicus gigas. Mar. Ecol. Prog. Ser. 441:165-175. Article

Steer, B. L. M., and G. D. Jackson.

2004. Temporal shifts in the allocation of energy in the arrow squid, Nototodarus gouldi: sex-specific responses. Mar. Biol. 144:1141-1149. Article

van der Vyver, J. S. F., W. H. H. Sauer, N. J. McKeown, D. Yemane, P. W. Shaw, and M. R. Lipinski.

2016. Phenotypic divergence despite high gene flow in chokka squid Loligo reynaudii (Cephalopoda: Loliginidae): implications for fishery management. J. Mar. Biol. Assoc. U.K. 96:1507-1525. Article

Young, R.E. and M. Vecchione.

1996. Analysis of morphology to determine primary sister-taxon relationships within coleoid cephalopods. Am. Malacol. Bull. 12:91-112. 